\title{
PENGARUH PENAMBAHAN GULA DAN KARAGENAN TERHADAP MUTU JELLY MENTIMUN
}

\section{The Influence of Sugar and Carrageenan Addition to Quality of Cucumber Jelly}

\author{
Kamsina* dan Inda Three Anova \\ Balai Riset dan Standardisasi Industri Padang \\ JI. Raya LIK No. 23 Ulu Gadut Telp. (0751) 72201 Fax.(0751) 71320 Padang 25164 \\ * e-mail: kamsinaina@gmail.com
}

Diterima: 18 Februari 2013 Disetujui: 30 April 2013

\begin{abstract}
ABSTRAK
Jelly adalah sejenis makanan ringan berbentuk semi padat yang terbuat dari sari buah-buahan yang dimasak dengan gula. Jelly sayuran dan buah-buahan adalah minuman yang dibuat dari bahan-bahan alami seperti mentimun yang diberi tambahan tepung pembuat jelly sebagai pengental, gula tebu sebagai pemanis, garam dan asam sitrat. Jelly mentimun mengandung unsur nutrisi dan bersifat fungsional, berkhasiat untuk mencegah darah tinggi, membersihkan pencernaan, meremajakan kulit dan lain-lain. Penelitian ini bertujuan untuk memberikan alternatif pengolahan mentimun menjadi jelly mentimun dan dapat meningkatkan nilai tambah serta daya simpan dari produk olahan mentimun. Rancangan penelitian menggunakan Rancangan acak lengkap (RAL) secara faktorial digunakan untuk melihat pengaruh penambahan gula $40 \%$, dan $30 \%$ serta variasi perlakuan penambahan karagenan $1 \%$ dan $0,75 \%$. Hasil penelitian menunjukkan bahwa perlakuan penambahan gula $30 \%$ dan karagenan $1 \%$ memberikan hasil jelly mentimun yang lebih disukai dari uji organoleptik rasa, aroma, warna dan cukup disukai dari organoleptik tekstur, sedangkan perlakuan kosentrasi gula $40 \%$ dan karagenan 1\% memberikan hasil yang tertinggi untuk kadar gula 22,99\%, kadar air 44,99\%, kadar abu $0,99 \%$. Semua perlakuan menunjukkan tidak adanya cemaran logam $\mathrm{Cu}, \mathrm{Sn}$, As dan $\mathrm{Pb}$, untuk cemaran mikroba seperti Kapang/Khamir dan Angka Lempeng Total tidak terdeteksi ( $<10$ koloni/g) serta bakteri Koliform $<2$ APM/g serta memiliki ketahanan simpan selama 3 bulan penyimpanan pada kondisi suhu $5-10^{\circ} \mathrm{C}$.
\end{abstract}

Kata kunci : mentimun, jelly, karagenan, gula

\section{ABSTRACT}

Jelly is a semi-solid form of snacks made from fruit juice which is cooked with sugar. Vegetables and fruits Jelly are a drink that is made from natural ingredients such as cucumber jelly maker given additional flour as a thickener, cane sugar as a sweetener, salt and citric acid. Cucumber jelly contains elements of nutritional and functional, efficacious for preventing high blood pressure, digestive cleanse, rejuvenate the skin and others. The purpose of this study to provide an alternative of cucumber processing became cucumber jelly and to increase the added value and shelf life of cucumbers processed products. Research design used a completely randomized design (CRD) in factorial used to see the effect of adding sugar $40 \%$, and $30 \%$ as well as the addition of carrageenan treatment variations $1 \%$ and $0.75 \%$. The results showed that the addition of sugar $30 \%$ and $1 \%$ carrageenan gave jelly yield of cucumber preferred organoleptic taste, aroma, color and texture was favored on the organoleptic, whereas treatment of sugar concentration $40 \%$ and $1 \%$ carrageenan gave the highest results for sugar $22.99 \%, 44.99 \%$ moisture content, ash content $0.99 \%$. All treatments showed no contamination of $\mathrm{Cu}$, Sn, As and Pb, for microbial contamination such as Fungus / Yeast and Total Plate Count undetectable (<10 colonies / $g$ ) as well as Coliform bacteria $<2$ APM / $g$ as well as shelflife for 3 months at storage temperature conditions $5-10^{\circ} \mathrm{C}$.

Key words: Cucumber, jelly, karagenan, sugar 


\section{PENDAHULUAN}

Buah mentimun (Cucumis sativus) merupakan salah satu buah yang cukup berpotensi di Indonesia terutama banyak tumbuh di daerah dataran rendah. Buah mentimun mudah didapat karena berbuah sepanjang tahun dengan buah yang cukup banyak. Menurut Badan Pusat Statistik (2010) potensi mentimun di Indonesia pada tahun 2009 mencapai 583.139 ton.

Buah mentimun banyak mengandung air dan enak dimakan dalam keadaan segar karena rasanya yang tawar dan menyegarkan. Kandungan zat gizi yang terdapat pada mentimun per 100 gram berat badan adalah energi 12 kalori, protein $0,7 \mathrm{~g}$, lemak $0,1 \mathrm{~g}$, karbohidrat 2,7 g, kalsium $10 \mathrm{mg}$, fosfor 21 $\mathrm{mg}$, besi $0,3 \mathrm{mg}$, vitamin A $0 \mathrm{RE}$, vitamin C $8,0 \mathrm{mg}$ dan vitamin B1 0,3 mg. Mereka yang menderita hipertensi disarankan untuk mengkonsumsi mentimun, karena kandungan mineralnya yaitu potassium, magnesium, dan fosfor (Depkes, 2000).

Di Indonesia sangat mudah menemukan buah mentimun setiap harinya sehingga memberikan prospek yang baik sebagai peluang usaha. Namun, potensi yang besar ini jika tidak dibarengi dengan pemanfaatan teknologi pengolahan yang tepat akan siasia. Kenyataan ini menjadi semakin parah jika musim buah tiba. Harga buah menjadi sangat murah bahkan banyak yang terbuang. Padahal buah mentimun dapat diolah menjadi produk jelly yang cukup diminati oleh konsumen karena mempunyai aroma yang khas sehingga dapat dipergunakan dalam pembuatan jelly (Wirakusumah, 2001).

Jelly adalah sejenis makanan ringan berbentuk semi padat yang terbuat dari sari buah-buahan yang dimasak dengan gula. Bahan utama yang diperlukan pada pembuatan jelly selain buah yakni karagenan, gula dan asam (Satuhu, 1994). Buah yang digunakan dalam pembuatan jelly dengan syarat antara lain buah yang masak/tidak terlalu matang, tidak ada tandatanda busuk dan rasa buah asam (Winarno, 1997).

Karagenan adalah bahan alami pembentuk gel yang terbuat dari rumput laut. Menurut Harijono, dkk (2001) rumput laut dapat dimanfaatkan sebagai bahan baku industri jelly, karagenan, alginat, dan furselaran. Produk hasil ekstraksi rumput laut banyak digunakan sebagai bahan pangan, bahan tambahan, atau bahan pembantu dalam industri makanan, farmasi, kosmetik, tekstil, kertas, cat, dan lain-lain. Karagenan dihasilkan dari rumput laut Euchema sp yang telah dibudidayakan di berbagai perairan Indonesia.

Karagenan dipakai secara luas karena kemampuannya yang sangat baik untuk membentuk gel dalam medium asam-gula. Untuk membentuk gel, karagenan harus ada senyawa pendehidrasi (biasanya gula) dan harus ditambahkan asam dengan jumlah yang cocok (de Man, 1997). Penambahan asam menurut Gaman dan Sherrington (1992) dapat meningkatkan kemampuan terbentuknya gel oleh karagenan.

Kekuatan jelly dipengaruhi oleh konsentrasi karagenan, jika konsentrasi karagenan rendah maka kekuatannya berkurang tetapi jika konsentrasi karagenen dan air berkurang maka jelly bersifat tegar (Winarno, 1996). Widya (2006) menyatakan dalam pembuatan jelly jambu duwet, penggunaan karagenan yang optimal adalah maksimal 1\%, sedangkan Satuhu (1994). menambahkan kandungan gula pada jelly tidak kurang dari $40 \%$. Selain berfungsi sebagai rasa manis gula juga berfungsi sebagai pengawet yang dapat mencegah /menghambat tumbuhnya mikroorganisme seperti jamur/kapang. Banyaknya gula yang ditambahkan tergantung pada kandungan asam dari buah tersebut. Semakin tinggi kandungan asam buahnya semakin banyak gula yang ditambahkan.

Berdasarkan hal tersebut di atas maka perlu dilakukan penelitian pemanfaatan mentimun menjadi jelly dan melihat pengaruh penambahan karagenan dan gula dalam pembuatan jelly mentimun untuk mendapatkan produk jelly mentimun yang baik dan disukai.

\section{METODOLOGIPENELITIAN}

\section{Bahan}

Bahan yang diperlukan adalah mentimun, gula, garam, vanile, asam sitrat, natrium benzoat, karagenan, bahan bakar, bahan kemasan dan bahan kimia untuk pengujian seperti Luff scrholl, Natrium Thio 
Sulfat, $\mathrm{HCl}, \mathrm{H}_{2} \mathrm{SO} 4, \mathrm{NaOH}$, Amylum, phenolptalein, $\mathrm{KI}, \mathrm{Pb}$ Asetat, Pepton Water, Potato Dextrose Agar, Plate Count Agar, Lactose Broth, Brilliant Green Lactose Broth dan Natrium Agar serta INVIC.

\section{Alat}

Peralatan yang digunakan meliputi; blender, dan peralatan pengujian neraca analitik, oven listrik, furnace, autoklaf, inkubator, laminar flow cabinet dan AAS

\section{Rancangan Penelitian}

Rancangan yang dilakukan adalah Rancangan Acak Lengkap secara faktorial yakni penambahan gula (A) $40 \%$ (A1), $30 \%(A 2)$ dan penambahan karagenan (B) $1 \%$ (B1), 0,75\% (B2). Data yang diperoleh diolah secara statistik dengan uji lanjutan metoda DNMRT pada taraf nyata $5 \%$.

\section{Pelaksanaan Penelitian}

Proses pembuatan jelly mentimun terlihat pada Gambar 1.

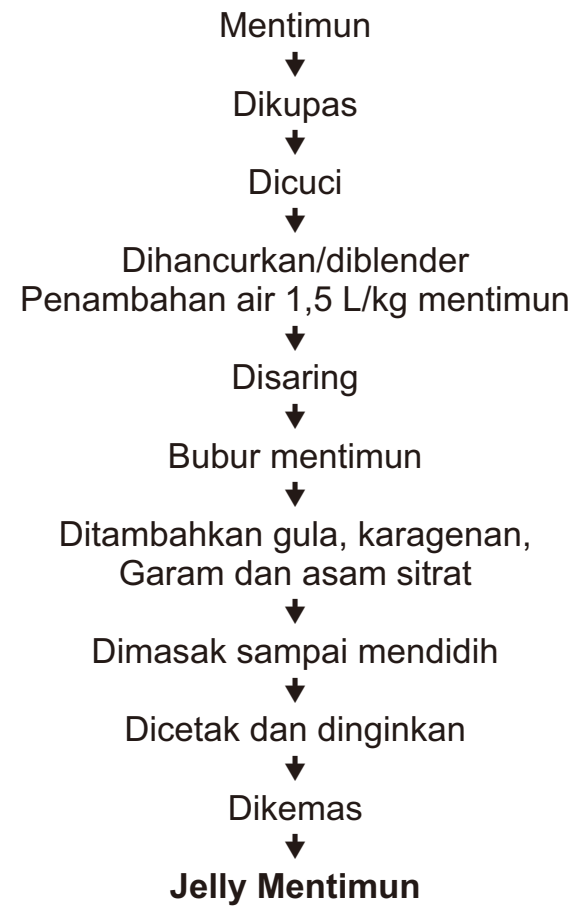

Gambar 1. Diagram alir pembuatan jelly mentimun

\section{Analisis}

Analisis kimia yang dilakukan terhadap produk jelly mentimun yakni kadar air, kadar gula dan kadar abu dan analisis mikrobiologi meliputi Kapang/khamir, bakteri koliform dan Angka Lempeng Total.

Uji organoleptik dilakukan oleh panelis berdasarkan tingkat kesukaan terhadap warna, aroma, rasa dan tekstur jelly mentimun dengan skala nilai : $5=$ sangat suka, 4 = suka, 3 = cukup suka, 2 = kurang suka dan 1 = tidak suka.

Ketahanan simpan dilakukan terhadap pertumbuhan bakteri atau Angka Lempeng Total (ALT) selama 3 bulan penyimpanan pada suhu $5-10^{\circ} \mathrm{C}$ dengan kemasan cup.

\section{HASIL DAN PEMBAHASAN}

\section{Kadar Air}

Perlakuan penambahan gula dan karagenan terhadap mutu jelly mentimun memberikan hasil yang berpengaruh sangat nyata terhadap kadar air jelly mentimun. Kadar air jelly mentimun seperti terlihat pada Gambar 2.

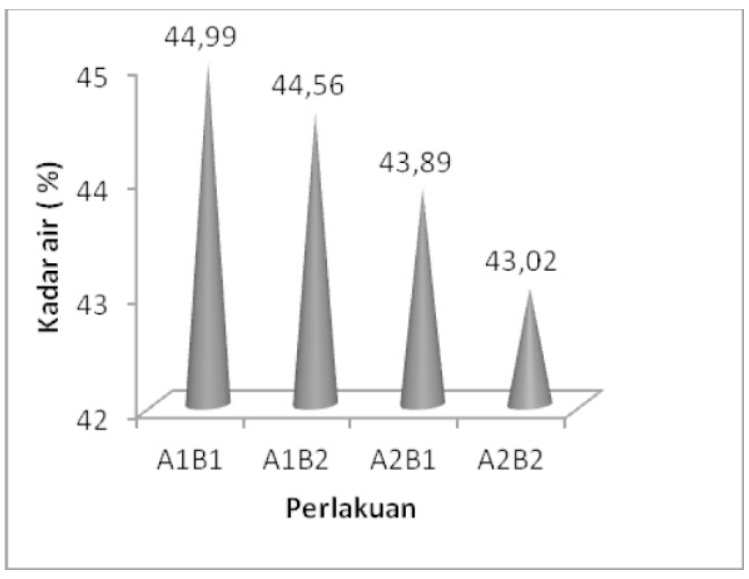

Gambar 2. Pengaruh penambahan gula dan karagenan terhadap kadar air jelly mentimun

Hasil analisis yang dilakukan secara statistik menunjukkan pengaruh yang sangat nyata terhadap kadar air dari jelly mentimun yang berarti penambahan gula dan karagenan sangat berpengaruh dalam pengolahan jelly mentimun. Dari Gambar 2 
dapat dilihat bahwa kadar air jelly mentimun yaitu $44,99 \%$ diperoleh pada penambahan gula $40 \%$ dan karagenan $1 \%$ dan berbeda dengan perlakuan lainnya, sedangkan kadar air terendah $43,02 \%$ didapatkan pada penambahan gula $30 \%$ dan karagenan 0,75\%. Menurut Winarno (1997), kadar air pada jelly akan semakin meningkat seiring dengan meningkatnya konsentrasi karagenan dan gula yang ditambahkan. Karena gel yang terbentuk oleh molekulmolekul karagenan pada mekanisme pembentukan jelly akan menyusun suatu pola jaringan tiga dimensi yang akan menarik cairan sehingga meningkatkan kadar air jelly. Parlina (2009) menambahkan karagenan digunakan dalam industri pangan karena fungsi karakteristiknya yang dapat digunakan untuk mengendalikan kandungan air dalam bahan pangan utamanya, mengendalikan tekstur, dan menstabilkan makanan.

Kadar air yang rendah pada perlakuan penambahan gula $30 \%$ dan karagenan $0,75 \%$ diduga terjadi karena lama pemasakan yang tidak homogen serta komposisi bahan yang berbeda. Menurut Winarno (1997) dengan komposisi bahan yang berbeda akan menyebabkan penguapan yang terjadi pada saat pemanasan juga berbeda, dimana ikatan hidrogen air yang terperangkap dalam jaringan tiga dimensi menjadi terputus sehingga kecepatan molekul air yang bergerak dengan cepatpun berbeda, membuat tekanan uap air meningkat dengan cepat sehingga terbentuk gas. Estiasih (2009) menyatakan bahwa kadar air suatu bahan dipengaruhi antara lain oleh luas pengeringan, suhu, kecepatan pergerakan udara, kelembaban udara, tekanan atmosfir, penguapan air dan lama pengeringan.

\section{Kadar Gula}

Perlakuan penambahan gula dan keragenan berpengaruh sangat nyata terhadap kadar gula jelly mentimun. Untuk analisis kadar gula jelly mentimun didapatkan kadar gula yang berkisar antara $20,32 \%$ - 22,99 \% dengan kadar gula tertinggi terdapat pada perlakuan kosentrasi gula $40 \%$ dan karagenan $1 \%$ dan terendah pada perlakuan kosentrasi gula $30 \%$ dan karagenan $0,75 \%$ seperti terlihat pada Gambar 3.

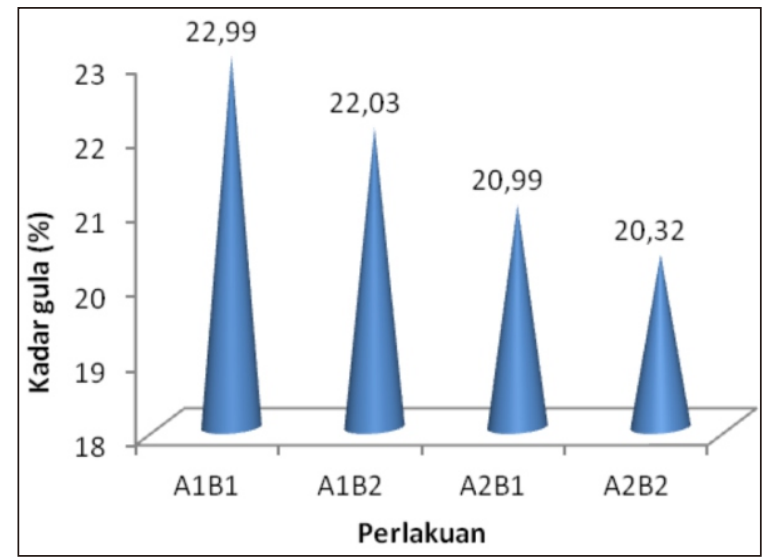

Gambar 3. Pengaruh penambahan gula dan karagenan terhadap kadar gula jelly mentimun

Pada Gambar 3 terlihat dengan meningkatnya jumlah gula dan karagenan yang diberikan akan meningkatkan kadar gula yang dikandung oleh jelly mentimun. Kadar gula untuk semua perlakuan jelly mentimun memenuhi Standar Nasional Industri (SNI 01-3552-1994) dimana kadar gula yang dipersyaratkan untuk jelly adalah minimal $20 \%$.

Karagenan lebih mudah terurai membentuk fraksi atau molekul yang lebih sederhana yaitu gula reduksi sehingga komponen gula sederhana (gula reduksi) tersedia lebih banyak. Menurut Winarno (2004), sukrosa (gula) yang dilarutkan dalam air dan dipanaskan maka akan terurai menjadi glukosa dan fruktosa yang disebut gula invert. Ditambahkan Desrosier (1988), bahwa sukrosa bersifat non pereduksi karena tidak mempunyai gugus $\mathrm{OH}$ yang bersifat reaktif, tetapi selama pemanasan dan dengan adanya asam, sukrosa dapat terhidrolisis menjadi gula invert yaitu fruktosa dan glukosa yang merupakan gula reduksi.

\section{Kadar Abu}

Perlakuan penambahan gula dan karagenan terhadap mutu jelly mentimun memberikan hasil yang berpengaruh sangat nyata terhadap kadar abu jelly mentimun. Kadar abu jelly mentimun seperti terlihat pada Gambar 4 
Abu merupakan zat organik sisa hasil pembakaran suatu bahan organik. Kadar abu ada hubungannya dengan mineral suatu bahan. Mineral suatu bahan merupakan garam organik (garam-garam malat, oksalat, asetat, pektat) dan garam anorganik (garam fosfat, karbonat, klorida, sulfat dan nitrat) (Fennema, 1996)

Kadar abu rata-rata pada berbagai kombinasi perlakuan persentase penambahan kadar gula dan karagenan berkisar antara $0,79-0,99 \%$ Abu sendiri adalah hasil reaksi unsur logam dengan oksigen, karena logam masa jenis lebih besar maka oksidanya tertinggal sebagai abu, sementara oksida non logam seperti $\mathrm{CO}_{2}$ karena ringan maka terbang sebagai asap.

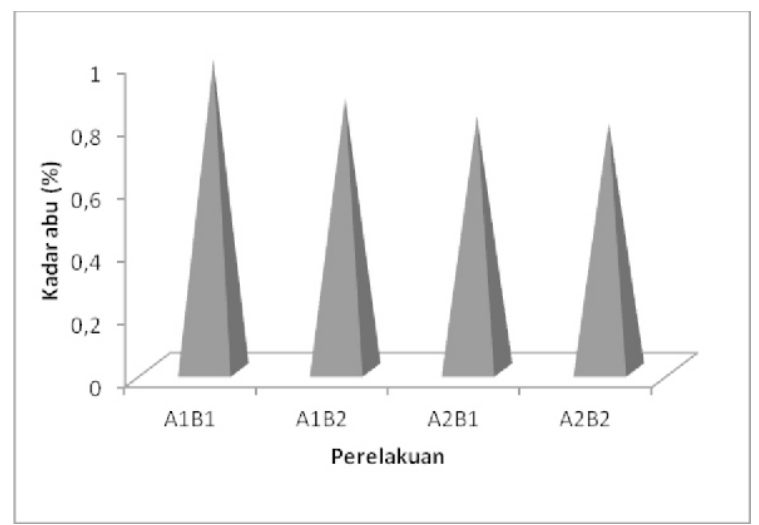

Gambar 4. Pengaruh penambahan gula dan karagenan terhadap kadar abu jelly mentimun

Selanjutnya Winarno (1994), menyatakan bahwa abu adalah sisa yang tertinggal setelah makanan dibakar sampai bebas karbon. Sisa yang tertinggal ini merupakan unsur-unsur mineral yang terdapat dalam suatu makanan atau makanan jadi (food product) yang dalam proses pengabuan unsur-unsur ini membentuk oksida-oksida atau bergabung dengan radikal negatif, sedangkan bahan organik yang lain dalam proses ini akan habis terbakar

\section{Uji Organoleptik}

Hasil uji organoleptik warna, aroma, rasa dan tekstur jelly mentimun yang dilakukan oleh panelis berdasarkan tingkat kesukaan menunjukkan pengaruh yang tidak nyata akibat perlakuan penambahan karagenan dan gula dalam pembuatan jelly mentimun, yang berarti penambahan karagenan gula tidak mempengaruhi penerimaan panelis terhadap warna, aroma, rasa dan tekstur.

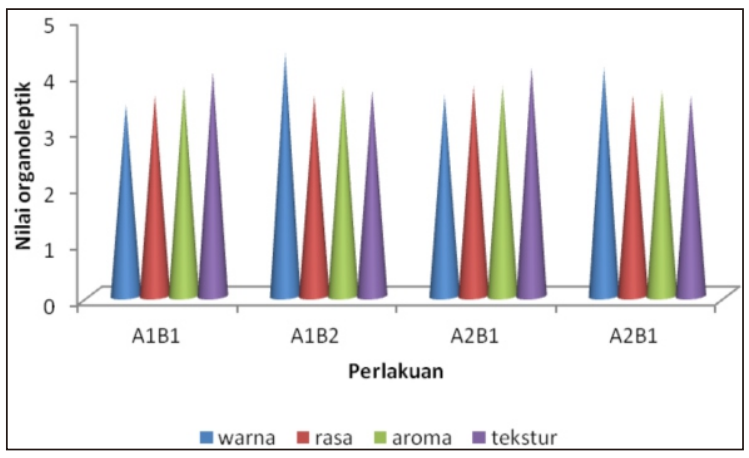

Gambar 5. Pengaruh penambahan gula dan karagenan terhadap organoleptik jelly mentimun

Hasil organoleptik seperti pada Gambar 5 terlihat bahwa perlakuan pemakaian gula $30 \%$ dengan karagenan $1 \%$ menunjukkan tingkat kesukaan warna tertinggi dari panelis dengan nilai 4,33. Hasil analisis statistik menunjukkan bahwa pembuatan jelly mentimun dengan penambahan gula dan karagenan memberikan pengaruh nyata terhadap rata-rata organoleptik warna. Warna merupakan hasil pengamatan dengan penglihatan yang dapat membedakan antara satu warna dengan warna lainnya, cerah, buram, bening, dan sebagainya. Salah satu sifat jelly adalah memiliki warna jernih, semakin jernih suatu produk jelly maka akan menunjukkan kualitas yang semakin baik,

Warna bahan pangan tergantung pada penampakan bahan pangan tersebut dan kemampuan dari bahan pangan memantulkan, menyebarkan, menyerap atau sinar tampak (Winarno, 1997). Produk jelly yang baik menurut Satuhu (1994) yaitu warna yang cerah, jernih (transparan), mempunyai konsentrasi yang baik seperti jelly tetapi tidak terlalu kaku atau keras dan mempunyai flavour (cita rasa) buah yang baik.

Penambahan gula dan karagenan tidak memberikan pengaruh nyata terhadap ratarata organoleptik rasa dari jelly mentimun. Perlakuan penambahan gula $30 \%$ dan karagenan $1 \%$ menunjukkan tingkat kesukaan rasa tertinggi dari panelis dengan nilai 3,75 (disukai). Bahan pangan pada 
umumnya tidak hanya memiliki salah satu rasa melainkan gabungan berbagai macam rasa secara terpadu. Rasa lebih banyak melibatkan panca indera yaitu lidah, dengan lidah senyawa dapat dikenali rasanya. Hasil uji organoleptik menunjukkan bahwa nilai rasa jelly mentimun berkisar antara 3,58 3,75 (disukai). Semakin tinggi nilai rasa, maka tingkat kesukaan panelis terhadap rasa jelly semakin besar.

Sedangkan pengaruh penambahan gula dan karagenan terhadap aroma dari jelly mentimun menunjukkan hasil yang berbeda tidak nyata, dengan nilai aroma yang sama antara perlakuan penambahan gula $40 \%$ dan karagenan $1 \%$, perlakuan penambahan gula $40 \%$ dan karagenan $0,75 \%$ serta perlakuan penambahan gula $30 \%$ dan karagenan $1 \%$ yakni bernilai 3,75 (disukai), sedangkan perlakuan penambahan gula $30 \%$ dan karagenan $0,75 \%$ mempunyai nilai rasa 3,67 . Berarti semua perlakuan terhadap rasa jelly mentimun disukai oleh panelis.

Aroma merupakan indikator yang penting dalam industri pangan karena dengan cepat dapat memberikan hasil penilaian diterima atau tidaknya produk tersebut. Aroma meliputi berbagai sifat seperti harum, amis, apek, busuk, dan sebagainya. Aroma atau bau sendiri sukar untuk diukur sehingga biasanya menimbulkan pendapat yang berlainan dalam menilai kualitas aromanya (Kartika 1988). Perbedaan pendapat disebabkan tiap orang memiliki perbedaan penciuman meskipun mereka dapat membedakan aroma namun setiap orang mempunyai kesukaan yang berlainan

Tingkat kesukaan panelis terhadap tekstur jelly mentimun dipengaruhi oleh variasi penambahan gula dan karagenan. Hal ini sesuai pendapat Winarno (1997) dan Desrosier (1988) bahwa kepadatan gel yang terbentuk ditentukan oleh banyaknya karagenan yang ditambahkan, semakin besar konsentrasi karagenan dan gula, semakin keras gel yang terbentuk.

Perlakuan penambahan gula $30 \%$ dan karagenan $1 \%$ memberikan nilai tektur yang tertinggi yaitu 4,08 (disukai) berbeda tidak nyata dengan perlakuan lainnya, sedangkan perlakuan penambahan gula $30 \%$ dan karagenan $0,75 \%$ memberikan nilai terendah yaitu 3,58 tapi tetap disukai oleh panelis.

Tekstur dari jelly mentimun merupakan sensasi tekanan yang dapat diamati dengan melihat dan dirasakan pada waktu digigit, dikunyah, ditelan ataupun perabaan dengan jari (Wahyuni, 2010). Tekstur jelly secara langsung dapat dilihat kenampakannya oleh konsumen berupa sifat lunak, liat, keras, halus, kasar, dan sebagainya, sehingga berpengaruh terhadap penilaian diterima atau tidaknya produk tersebut.

\section{Cemaran Logam}

Hasil analisis cemaran logam menunjukkan bahwa jelly mentimun yang dihasilkan tidak mengandung logam. Berdasarkan SNI 01-3552-1994 mengenai Jelly, kandungan Timbal $(\mathrm{Pb})$ maksimal 0,5 $\mathrm{mg} / \mathrm{kg}$, Tembaga (Cu) maksimal $5,0 \mathrm{mg} / \mathrm{kg}$, Seng (Zn) maksimal 29 mg/kg, Timah (Sn) maksimal $40 \mathrm{mg} / \mathrm{kg}$ dan Arsen (As)maksimal $0,1 \mathrm{mg} / \mathrm{kg}$. Tidak adanya cemaran logam yang ditemukan pada jelly mentimun menunjukkan bahwa bahan-bahan dan alatalat yang digunakan dalam pembuatan jelly bebas dari kontaminasi logam berat tersebut, sehingga produk dapat dikategorikan memiliki kualitas yang baik.

\section{Mikrobiologi}

Pengamatan secara mikrobiologi untuk parameter uji baik kapang/khamir maupun Angka Lempeng Total untuk semua perlakuan menunjukkan hasil tidak terdeteksi ( $<10 \mathrm{koloni} / \mathrm{g}$ ), sedangkan untuk parameter bakteri Koliform, semua perlakuan hasilnya negatif $(<3$ APM/g). Sesuai dengan SNI Jelly No. 01-3552-1994 parameter Angka Lempeng Total yang dipersyaratkan adalah maksimal 10.000 koloni $/ g$ dan bakteri koliform maksimal $20 \mathrm{APM} / \mathrm{g}$. Menurut Fachruddin (1998), adanya mikroba dalam suatu produk makanan, akan dapat menyebabkan kerusakan pada makanan, dimana mikroba akan memanfaatkan pangan untuk metabolismenya yang dapat menyebabkan pengasaman dan pembusukan daripada makanan. Friedheim (2001) menambahkan adanya bakteri koliform menunjukkan adanya polusi kotoran pada air yang digunakan. Bahaya terbesar sehubungan 
dengan produk pangan adalah bila air yang digunakan untuk produk pangan tersebut telah tercemar oleh bahan buangan atau kotoran manusia atau hewan berdarah panas. Bila hal ini terjadi dapat menyebabkan timbulnya penyakit demam usus atau disentri bagi manusia yang mengkonsumsinya.

\section{Ketahanan Simpan}

Angka Lempeng Total (ALT) atau jumlah pertumbuhan bakteri dari jelly mentimun yang disimpan pada suhu refrigerator selama penyimpanan menunjukkan terjadinya peningkatan dapat dilihat seperti pada Gambar 6. Nilai tertinggi didapatkan pada perlakuan penambahan gula $30 \%$ dan karagenan $0,75 \%$ dengan nilai jumlah bakteri 1.900 koloni/g. Terjadinya kenaikan pertumbuhan bakteri ini sejalan dengan bertambahnya waktu penyimpanan, penyerapan udara di sekitarnya cepat terjadi sampai terjadi keseimbangan.

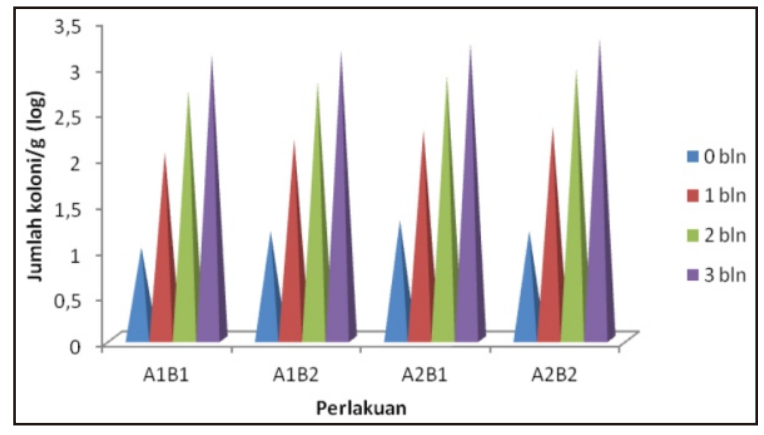

Gambar 6. Nilai logaritma bakteri (ALT) jelly mentimun selama penyimpanan.

Menurut Winarno (1994) kemampuan mikroba untuk bertahan hidup dan berkembang berkaitan dengan faktor ekstrinsik diantaranya suhu, kelengasan udara, konsentrasi gas dalam lingkungan hidupnya. Desrosier (1988) menambahkan, pengaruh atau hubungan antara kualitas produk dengan kondisi penyimpanan dipengaruhi oleh beberapa faktor yaitu jenis dan kualitas bahan baku yang digunakan seperti kadar air, zat gizi, metoda keefektifan pengolahan yang menyebabkan seluruh perubahan dalam aseptabilitas produk, jenis dan keadaan pengemasan dan juga pengaruh yang ditimbulkan oleh suhu dan kelembaban penyimpanan.

Selain itu dengan berkurangnya kosentrasi gula dan karagenan juga meningkatkan pertumbuhan bakteri. Margono (1993) menyatakan bahwa tingginya kadar gula di dalam bahan selain memberikan rasa manis, juga berfungsi untuk mengawetkan bahan pangan. Basuki et al (2005) menambahkan gula selain berfungsi sebagai rasa manis, juga berfungsi sebagai pengawet pada pangan. Apabila gula ditambahkan dalam bahan pangan dengan kosentrasi tinggi, sebagian air yang ada menjadi tidak tersedia untuk pertumbuhan mikrorganisme, karena sebagian air tersebut berikatan dengan gula. Parlina (2009) menyatakan karagenan dalam pangan dapat berfungsi untuk mengendalikan kandungan air dalam bahan pangan utamanya dan mengendalikan tekstur serta menstabilkan makanan,

Ketahanan simpan dari jelly mentimun, sampai 3 bulan yang disimpan pada suhu 5$10^{\circ} \mathrm{C}$ masih baik, baik dari kadar air maupun dilihat secara visual, sedangkan pada minggu ke 15 produk jelly mentimun secara visual sudah mulai berlendir yang disebabkan oleh adanya aktivitas bakteri pada produk tersebut.

\section{KESIMPULAN}

Berdasarkan hasil yang diperoleh dari penelitian pengaruh penambahan gula dan karagenan dalam pembuatan jelly mentimun didapat kesimpulan sebagai berikut :

1. Perlakuan perbedaan penambahan jumlah gula dan karagenan berpengaruh nyata terhadap kadar gula, air, abu, dan warna tetapi berpengaruh tidak nyata terhadap, rasa, aroma, dan tekstur jelly mentimun.

2. Pembuatan jelly mentimun dengan penambahan gula $30 \%$ dan karagenan $1 \%$ memberikan hasil optimal dengan uji organoleptik warna, rasa, aroma dan tekstur lebih disukai dibanding perlakuan lain, sedangkan perlakuan konsentrasi gula $40 \%$ dan karagenan $1 \%$ memberikan hasil yang optimal untuk kadar gula 22,99\%, kadar air $44,99 \%$, kadar abu $0,99 \%$ serta daya simpan lebih dari 3 bulan. 
3. Semua perlakuan menunjukkan tidak adanya cemaran logam seperti logam $\mathrm{Cu}, \mathrm{Sn}, \mathrm{As}$ dan $\mathrm{Pb}$ demikian juga untuk cemaran mikroba seperti Kapang/Khamir dan ALT jumlahnya 0 (<10 koloni/g) serta bakteri Koliform 0 $(<2 \mathrm{APM} / \mathrm{g})$

\section{DAFTAR PUSTAKA}

Badan Pusat Statistik. 2010. Produksi Buahbuahan di Indonesia. BPS. Jakarta.

Badan Standardisasi Nasional. 1994. SNI Jelly 01-3552-1994. Jakarta

Basuki, E.K., Rosida dan Rusmiati, E. 2005. Studi Keawetan Roti Manis yang Beredar di Kecamatan Rungkut Surabaya. Jurnal Teknologi Pangan dan Hasil Pertanian. Vol.3 (2):97-106.

De Man, J.M. 1997. Kimia makanan. Penerbit ITB. Bandung.

Desrosier, Norman W. 1988. Teknologi pengawetan pangan. UI Press. Jakarta.

Direktorat Gizi Departemen Kesehatan. 2000. Komposisi Bahan Bahan Makanan. RI. Jakarta. Bhatara Karya Aksara.

Estiasih. 2009. Ilmu dan Teknologi Pangan. Graha llmu. Yogyakarta.

Fachruddin, L. 1998. Memilih dan Memanfaatkan Bahan Tambahan Makanan. Trubus Agriwidya. Bogor.

Fannema, 1996. Food Chemistry, Third Edition. Taylor \& Francis. ISBN. 0824793463,9780824793463

Friedheim, E dan Michaelis, L. 2001. $\underline{\text { Human }}$ targets of Pseudomonas aeruginosa pyocyanin Jurnal Biology. Chem. 91,55-368. Cit. Porter ,J.R
Gaman, P.M. dan Sherrington. 1992. Pengantar ilmu pangan nutrisi dan mikrobiologi. Gadjah Mada University Press. Yogyakarta.

Harijono, JK dan J.A. Mustijasari, 2001. Pengaruh Kadar Karaginan Dan Total Padatan terlarut Sari Buah Apel Muda terhadap Aspek Kualitas Permen Jelly. Jurnal Teknologi Pertanian Vol, 2 No.2

Kartika, B., P. Hastuti dan W. Supartono, 1988. Pedoman Uji Inderawi Bahan Pangan. PAU Pangan dan Gizi. UGM. Yogyakarta

Lembaga Pembinaan dan Perlindungan Konsumen. 1994. Waspada sebelum celaka seputar makanan dan minuman. Puspa Swara. Semarang.

Margono, T., Suryati, D. dan Hartinah, S. 1993. Teknologi Pangan. PDII-LIPI. Jakarta.

Parlina I. 2009. Karagenan, produk olahan rumput laut merah Indonesia yang sangat bermanfaat http://iinparlina.word-press.com diunggah tanggal 21 September 2012.

Satuhu, S. 1994. Penanganan dan pengolahan buah. Penebar. Jakarta.

Wahyuni, R, 2010. Optimasi Pengolahan Kembang Gula Jelly Campuran Kulit dan Buah Naga Super Merah (Hylocereus costaricensis) dan Prakiraan Biaya Produksi. Program Pascasarjana Universitas Brawijaya. Swadaya. Jakarta.

Widya, PD. 2006. Studi Pembuatan Jelly Jambu Duwet. [Thesis]. Fakultas Teknologi Pertanian. Universitas Andalas. Padang.

Winarno, F.G dan Rahayu, T.S. 1994. Bahan Tambahan untuk Makanan dan Kontaminan. Pustaka Sinar Harapan. Jakarta. 
Winarno, F.G. 1996. Teknologi Pengolahan Rumput Laut. PT. Gramedia. Jakarta.

Winarno, F.G. 1997. Kimia pangan dan gizi. Gramedia. Jakarta.
Winarno, F.G. 2004. Kimia Pangan dan Gizi. PT. Gramedia Pustaka Utama. Jakarta.

Wirakusumah, E.S. 2001. Buah dan sayur untuk terapi. Penebar Swadaya. Jakarta. 